\title{
Cross-cultural adaptation of the Quality of Life Index Spinal Cord Injury - Version III*
}

\author{
Adaptação transcultural do Quality of Life Index Spinal Cord Injury - Version III \\ Adaptación transcultural del Quality of Life Index Spinal Cord Injury - Version III
}

Priscila Alencar Mendes Reis ${ }^{1}$, Zuila Maria de Figueiredo Carvalho², Juan José Tirado Darder ${ }^{3}$, Mônica Oliveira Batista Oriá $^{2}$, Rita Mônica Borges Studart ${ }^{4}$, Samia Jardelle Costa de Freitas Maniva ${ }^{1}$

${ }^{1} \mathrm{PhD}$ Student, Post Graduate Program in Nursing, Federal University of Ceará, Fortaleza, CE, Brazil.

2 Professor, PhD, Post Graduate Program in Nursing, Federal University of Ceará, Fortaleza, CE, Brazil.

3 Professor, PhD, Faculty of Health Sciences, University CEU Cardenal Herrera, Valencia, Spain.

${ }^{4}$ Professor, $\mathrm{PhD}$, Edson Queiroz Foundation, University of Fortaleza, Fortaleza, CE, Brazil.

\footnotetext{
Corresponding author:
}

Priscila Alencar Mendes Reis

Rua Augusto Calheiros, 1218

CEP 60863-290 - Fortaleza, CE, Brazil

prialencarmendes@hotmail.com

\begin{abstract}
Objective: To translate and culturally adapt to Portuguese the Ferrans and Powers Quality of Life Index Spinal Cord Injury - Version III and characterize the sample in relation to sociodemographic and clinical aspects. Method: A methodological study with view to cross-cultural adaptation, following the particular steps of this method: initial translation, translation synthesis, back-translation (translation back to the original language), review by a committee of judges and pretest of the final version. The pretest was carried out with 30 patients with spinal cord injury. Results: An index of 74 items divided into two parts (satisfaction/importance) was obtained. The criteria of semantic equivalence were evaluated as very adequate translation, higher than $87 \%$, and vocabulary and were grammar higher than $86 \%$. Idiomatic equivalence was higher than $74 \%$, experimental greater than $78 \%$ and conceptual was greater than $70 \%$. Conclusion: After cross-cultural adaptation, the instrument proved semantic, idiomatic, experimental and conceptual adequacy, in addition to helping the evaluation of the quality of life of people with spinal cord injury.
\end{abstract}

\section{DESCRIPTORS}

Spinal Cord Injuries; Quality of Life; Cross-Cultural Comparison; Validation Studies; Rehabilitation Nursing. 


\section{INTRODUCTION}

Spinal cord injury (SCI) is a disabling neurological syndrome that leads to systemic repercussions, as well as psychological, social, economic and labor changes $^{(1-2)}$. People affected by SCI are identified as disabled. In Brazil, it is estimated that from the 2010 census there will be 16 million people with disabilities ${ }^{(3)}$.

Despite the disabilities caused by the spinal cord injury, in recent years there have been technological advances in healthcare for controlling the symptoms and prolonging life. The need to live with quality stands out in this context, therefore, the resources for measuring quality of life (QOL) of people with chronic health conditions became indispensable ${ }^{(4)}$.

The use of instruments such as indexes/scales allows the evaluation of which QOL domain is affected and better developed in people with SCI hence, enabling to implement care and health promotion strategies. Within this context, the Ferrans and Powers Quality of Life (QLI) stands out in its specific version for spinal cord injury, known as $Q L I S p i-$ nal Cord Injury - Version III. It was developed by Carol Estwing Ferrans and Powers Marjorie in 1984, and is a Likert scale that assesses QOL with items distributed in domains of health and functioning, psychological and spiritual, economic, and social and family ${ }^{(5)}$.

However, it was identified a lack of reliable studies addressing QOL in people with SCI using specific instruments. A literature search was carried out to continue research in this area and evaluate the QOL of individuals with spinal cord injury. The scarcity of scales/indexes aiming at measuring QOL specifically for people with SCI in Brazil became evident. This search was made in the databases of the Virtual Library in Health (VHL), which included the Latin American and Caribbean Health Sciences (LILACS), Medical Literature Analysis and Retrieval System Online (MEDLINE), National Library of Medicine (PubMed), Cumulative Index of Nursing and Allied Health Literature (CINAHL) using, respectively, an uncontrolled descriptor and two controlled descriptors registered in DeCS and MeSH, in Portuguese and English: Escalas/Scales, Qualidade de vida/Quality of Life and Lesões da Medula Espinhal/Spinal Cord Injuries. Following this survey, searches were carried out in specific sites of QOL, identified in the references of these articles in the VHL.

Among generic and specific, were found 99 QOL instruments. After an individual assessment of each instrument, it was found that only the Ferrans and Powers Quality of Life (QLI) had a specific version for spinal cord injury called QLI Spinal Cord Injury - Version III. According to Ferrans and Powers ${ }^{(5)}$, this particular scale had not been translated, adapted and validated for the Portuguese language yet. Permission was granted by Ferrans for translation, adaptation and validation of this index.

The translation and cultural adaptation of such a tool could be a way of obtaining a more efficient intervention, aiming at the well-being of people with spinal cord injury, since it will identify and encourage the promotion of health and QOL. Furthermore, this study is expected to provide theoretical basis on the impact of SCI in QOL aspects of patients.

The objective of the study was to translate and culturally adapt to Portuguese the Ferrans and Powers Quality of Life Index Spinal Cord Injury - Version III and characterize the sample in terms of sociodemographic and clinical aspects.

\section{METHOD}

This is a methodological study with a view to crosscultural adaptation of the Ferrans and Powers Quality of Life Index Spinal Cord Injury - Version III, following the particular steps of this method: initial translation, translation synthesis, back-translation, review by a committee of judges and finally, pretest of the final version ${ }^{(6)}$. In order to carry out the present study, permission to use the index was given by the lead author by email. The translated version was back-translated into the original language by a blind procedure, in which the translators did not have access to the English version (original) of the index. The two translators responsible for the back-translation were bilingual, with English as mother tongue, and were informed of the concepts explored.

The study was carried out in Fortaleza, state of Ceará. The sample consisted of six translators, five judges and 30 patients with $\mathrm{SCI}^{(7)}$. The choice of judges was through a search in the lattes platform using the following crite$\mathrm{ria}^{(8)}$ : professional experience or scientific production in the thematic of neurological diseases, spinal cord injury, quality of life and instrument validation; title of $\mathrm{PhD}$, master or specialist with grade higher than five.

The sample for the pretest of the translated version consisted of 30 people with spinal cord injuries, as recommended in the literature ${ }^{(9)}$. It was selected by searching in a database of 132 people with spinal cord injuries registered in the database of the Research and Extension Core in Neurological Nursing (NUPEN - Núcleo de Pesquisa e Extensão em Enfermagem Neurológica NUPEN), linked to the Federal University of Ceará. This database was chosen for its easy access to the sample. Initially the residents in the city of Fortaleza were selected. Then, people from the alphabetical order list were randomly contacted. When these contacts were successful, phone calls were made to schedule the interviews. In case the communication was not established, visits were made to people's homes.

The following inclusion criteria were adopted: people with SCI living in the city of Fortaleza with at least four years of school education after literacy, as recommended by Ferrans and Powers when the index is selfadministered, and acceptance to participate in the study by signing the Terms of Consent. The exclusion criteria were people who could not answer questions for having 
poor health, such as two patients with quadriplegia and on tracheostomy.

The pretest application of the Quality of Life Index Spinal Cord Injury - Version III in the Portuguese version occurred in the homes of participants as an interview to ensure understanding of the questions, as suggested by the author. A form was also used to identify the sociodemographic and clinical characteristics of people with spinal cord injury, which enabled to correlate the mode/ lifestyle of these people with the QOL domains.

The data regarding the judges' evaluation of items were entered into the Microsoft ExcelTM and the sociodemographic and clinical characteristics of people with SCI entered into the Microsoft AccessTM. Data were subsequently exported to the STATA statistical software, version 11 , for generating the results. Then came the analysis of agreement among the responses of the five judges concerning the reviews of semantic, idiomatic, conceptual and experimental equivalence. For all items, in the semantic evaluation of the judges' responses, were used univariate frequency distributions, descriptive measures (mean and standard deviation), kappa coefficient of Cohen and the percentage of agreement of items with very adequate translation (VAT). The level of significance adopted was $5 \%(\mathrm{p} \leq 0.05)$. The next step was the sociodemographic and clinical characterization of the target audience.

National and international standards of ethics in research involving human subjects were followed to conduct the present study ${ }^{(10)}$, approved under number $344.927 / 2013$ by the Ethics Committee of the Federal University of Ceará.

\section{RESULTS}

With respect to the sociodemographic characteristics of patients with SCI, $73.3 \%$ were male; average age around 38.4 years ( $\mathrm{SD}=14.1$ years); $70 \%$ were born in Fortaleza, 20\% in the interior of the state of Ceará and $10 \%$ from other states. The prevalent education was incomplete secondary school (33\%). Regarding marital status, $50 \%$ were married/in common-law marriage, $46.7 \%$ were single and $3.3 \%$ widowed; most were retired due to disability (86.6\%). As for clinical characteristics, $66.7 \%$ had injury in the thoracic region; $56.7 \%$ had more than five years of injury and $63.3 \%$ did not participate in a rehabilitation program. The causes of SCI were the following: $26.7 \%$ caused by firearm projectile (FAP), 20\% by high falls and other causes, $16.7 \%$ by car accidents, $10 \%$ by diving in shallow water and $6.6 \%$ by falling from one's own height.

The cross-cultural adaptation was carried out by six translators who translated the index, and by a five-judge committee, which analyzed the items in the index regarding the semantic, language, cultural and experimental equivalence. Five professional nurses participated in the committee of judges. They evaluated the semantic equivalence of the index in relation to spelling, vocabulary and grammar, which were assessed as Very Adequate Translation (VAT) by more than $70 \%$.

The kappa coefficient $(\kappa)$ and the percentage of agreement among the judges regarding the semantic equivalence criterion - spelling, vocabulary and grammar - were applied to the four categories (Very Adequate Translation - VAT, Proper Translation - PT, Translation With Inadequacies - TWI, Totally Inadequate Translation TII). In relation to spelling, the judge who had the best agreement among the pairs was judge number five. However, there was considerable agreement between judges number two and five, and between judges number one and five, both statistically significant ( $p \leq 0.05$ ). Regarding vocabulary and grammar, the judges who showed best agreement between pairs were numbers one and five.

In relation to evaluation of idiomatic equivalence, the percentage of items assessed as Very Adequate Translation (VAT) was above $74 \%$, and judges number one and two expressed greater variations in the evaluations of items. In the experimental evaluation, the percentage of items considered as VAT was above $78 \%$, which is a distribution of responses similar to the idiomatic equivalence for the judges number one and two. In conceptual evaluation, the percentage of items assessed as VAT was higher than $70 \%$ and the distribution of responses was similar to the previous criteria. The item 11 and the title of the index were reported as Totally Inadequate Translation $(1.2 \%)$.

Thus, given the semantic equivalence of the Portuguese version, some changes were suggested by the committee of judges: change of the instrument title to facilitate understanding of the purpose of index, leaving as Spinal Cord Injury and Quality of Life - Version III; change of the guiding question and items of the parts one and two, as shown in table 1 , as well as the percentage of judges' general agreement.

Thus, the mentioned data indicate excellent overall agreement among judges. The content of the index that was translated and adapted from English into Portuguese especially for people with spinal cord injury residing in Fortaleza covers common situations in the daily life of both nations. Therefore, its cultural adaptation is confirmed in the reality of Brazil for people with spinal cord injury.

Table 1 and Chart 1 show some changes in the Portuguese version consolidated by the judges for application in the pretest. The instrument consists of 74 items. However, due to limited space of this article, only the items in which changes were proposed are shown in chart 1 . To maintain consistency with the items of the instrument, the same numbering of the original item is adopted in the table and the headers are kept.

Thus, there were 39 changes among the 74 items of the instrument. The judges suggested changes in 35 items and the patients in six items. Among these suggestions, two were common to patients and judges. 
Table 1 (Parts 1 and 2) - Semantic equivalence between the Portuguese version of the Quality of Life Index Spinal Cord Injury Version - III and the original in English - Fortaleza, CE, Brazil, 2014.

Items of the index Ferrans and Powers Quality of Life Index Spinal Cord Injury - Version III

Semantic

evaluation of Items

$(\%)$

Judges'

agreement

VAT

Back-translation

Pre-final version

\begin{tabular}{|c|c|c|}
\hline Item & Original & Translation \\
\hline & $\begin{array}{l}\text { Ferrans and Powers Quality } \\
\text { of Life Index Spinal Cord } \\
\text { Injury - Version III }\end{array}$ & $\begin{array}{l}\text { Índice de Qualidade de } \\
\text { Vida de Corda Espinhal } \\
\text { Danificada de Ferrans and } \\
\text { Powers - Versão III }\end{array}$ \\
\hline & $\begin{array}{l}\text { PART 1. For each of the } \\
\text { following, please choose the } \\
\text { answer that best describes } \\
\text { how satisfied you are with } \\
\text { that area of your life. Please } \\
\text { mark your answer by circling } \\
\text { the number. There are no } \\
\text { right or wrong answers. }\end{array}$ & $\begin{array}{l}\text { PARTE 1. Para cada dos } \\
\text { seguintes itens, por favor, } \\
\text { escolha a resposta que } \\
\text { melhor descrever quão } \\
\text { satisfeita você está com } \\
\text { essa área de sua vida. Por } \\
\text { favor, marque sua resposta } \\
\text { circulando o número. Não há } \\
\text { respostas (certo) ou (errado). }\end{array}$ \\
\hline
\end{tabular}

Ferran's and Power's

Quality of Life Index

Spinal Cord Injuries Version III

PART ONE: For each of

the following items, please choose the response that

best describes how satisfied you are with this area of your life. Please mark your response by circling the

number correlating to the description. There are no right or wrong answers.

\begin{tabular}{|c|c|c|c|c|c|}
\hline & How satisfied are you with: & $\begin{array}{l}\text { Quão satisfeito você está } \\
\text { com: }\end{array}$ & $\begin{array}{l}\text { How satisfied are you } \\
\text { with: }\end{array}$ & $\begin{array}{l}\text { Qual o nível de } \\
\text { satisfação em relação } \\
\text { a (ao): }\end{array}$ & 60.0 \\
\hline & Very Dissatisfied & Muito Insatisfeito & Very Dissatisfied & Muito Insatisfeito & \multirow{6}{*}{100.0} \\
\hline & Moderately Dissatisfied & Moderadamente Insatisfeito & Moderately Dissatisfied & $\begin{array}{l}\text { Moderadamente } \\
\text { Insatisfeito }\end{array}$ & \\
\hline & Slightly Dissatisfied & Pouco Insatisfeito & Slightly Dissatisfied & Pouco Insatisfeito & \\
\hline & Slightly Satisfied & Pouco Satisfeito & Slightly Satisfied & Pouco Satisfeito & \\
\hline & Moderately Satisfied & Moderadamente Satisfeito & Moderately Satisfied & $\begin{array}{l}\text { Moderadamente } \\
\text { Satisfeito }\end{array}$ & \\
\hline & Very Satisfied & Muito Satisfeito & Very Satisfied & Muito Satisfeito & \\
\hline 03 & $\begin{array}{l}\text { The amount of pain that you } \\
\text { have? }\end{array}$ & $\begin{array}{l}\text { A quantidade de dor que } \\
\text { você tem? }\end{array}$ & $\begin{array}{l}\text { The amount of pain you } \\
\text { experience? }\end{array}$ & $\begin{array}{l}\text { Quantidade de dor que } \\
\text { vocêsente? }\end{array}$ & 100.0 \\
\hline 05 & $\begin{array}{l}\text { Your ability to take care of } \\
\text { yourself without help? }\end{array}$ & $\begin{array}{l}\text { Sua capacidade para se } \\
\text { cuidar sozinho? }\end{array}$ & $\begin{array}{l}\text { Your ability to take care of } \\
\text { yourself? }\end{array}$ & $\begin{array}{l}\text { Sua capacidade para } \\
\text { cuidar de você mesmo } \\
\text { sem ajuda? }\end{array}$ & 80.0 \\
\hline 07 & $\begin{array}{l}\text { Your ability to clear your } \\
\text { lungs? }\end{array}$ & $\begin{array}{l}\text { Sua capacidade de } \\
\text { desobstruir seus pulmões? }\end{array}$ & $\begin{array}{l}\text { Your ability to clear your } \\
\text { lungs? }\end{array}$ & $\begin{array}{l}\text { Sua capacidade de } \\
\text { limpar seus pulmões? }\end{array}$ & 100.0 \\
\hline 08 & $\begin{array}{l}\text { The amount of control you } \\
\text { have over your life? }\end{array}$ & $\begin{array}{l}\text { A quantidade de controle } \\
\text { que você tem sobre sua vida? }\end{array}$ & $\begin{array}{l}\text { The amount of control you } \\
\text { have over your life? }\end{array}$ & $\begin{array}{l}\text { Controle que você tem } \\
\text { sobre sua vida? }\end{array}$ & 93.3 \\
\hline 11 & Your children? & Seus filhos? & Your children? & $\begin{array}{l}\text { Seus filhos? (Se você } \\
\underline{\text { tiver ou não) }}\end{array}$ & 100.0 \\
\hline 15 & $\begin{array}{l}\text { Your spouse, lover, or partner } \\
\text { (if you have one)? }\end{array}$ & $\begin{array}{l}\text { Seu esposo, amante ou } \\
\text { companheiro (se você tiver)? }\end{array}$ & $\begin{array}{l}\text { Your spouse, lover or } \\
\text { partner (if you have)? }\end{array}$ & $\begin{array}{l}\text { Seu/Sua esposo } \\
\text { (a), amante ou } \\
\text { companheiro_(a) (se } \\
\text { você tiver)? }\end{array}$ & 93.3 \\
\hline 16 & $\begin{array}{l}\text { Not having a spouse, lover } \\
\text { or partner (if you do not have } \\
\text { one)? }\end{array}$ & $\begin{array}{l}\text { Em não ter esposo, amante } \\
\text { ou companheiro (se não } \\
\text { tiver)? }\end{array}$ & $\begin{array}{l}\text { Not having a spouse, } \\
\text { lover, or companion (if you } \\
\text { do not have one)? }\end{array}$ & $\begin{array}{l}\text { Não ter esposo } \\
\text { (a), amante ou } \\
\text { Companheiro } \underline{(a)} \text { (se } \\
\text { não tiver)? }\end{array}$ & 93.3 \\
\hline & Please Go To Next Page & $\begin{array}{l}\text { Por favor, vá para a próxima } \\
\text { página }\end{array}$ & Please go to the next page & $\begin{array}{l}\text { Por favor, passe para a } \\
\text { próxima página }\end{array}$ & 100.0 \\
\hline 18 & $\begin{array}{l}\text { The emotional support you } \\
\text { get from your family? }\end{array}$ & $\begin{array}{l}\text { O apoio emocional que você } \\
\underline{\text { tem de sua família? }}\end{array}$ & $\begin{array}{l}\text { The emotional support you } \\
\text { get from your family? }\end{array}$ & $\begin{array}{l}\text { O apoio emocional } \\
\text { que você recebe de sua } \\
\text { família? }\end{array}$ & 100.0 \\
\hline 19 & $\begin{array}{l}\text { The emotional support you } \\
\text { get from people other than } \\
\text { your family? }\end{array}$ & $\begin{array}{l}\text { O apoio emocional que você } \\
\text { tem de outras pessoas que } \\
\underline{\text { não são da sua família? }}\end{array}$ & $\begin{array}{l}\text { The emotional support you } \\
\text { get from people outside of } \\
\text { your family? }\end{array}$ & $\begin{array}{l}\text { O apoio emocional que } \\
\text { você recebe de pessoas } \\
\text { além da sua família? }\end{array}$ & 100.0 \\
\hline
\end{tabular}

continued...

\section{Índice Lesão Medular e Qualidade de Vida - Versão III}

53.3

PARTE 1. Para os itens

seguintes, por favor, escolha a resposta que melhor descrever o seu grau de satisfação com as áreas de sua vida. Indique sua resposta circulando o número. Não há respostas certas

ou erradas.

\section{Qual o nível de} a (ao):

Muito Insatisfeito

Insatisfeito

Pouco Insatisfeito

Satisfeito

Quantidade de dor que

Sua capacidade para cuidar de você mesmo

Sua capacidade de par seus pulmões? 


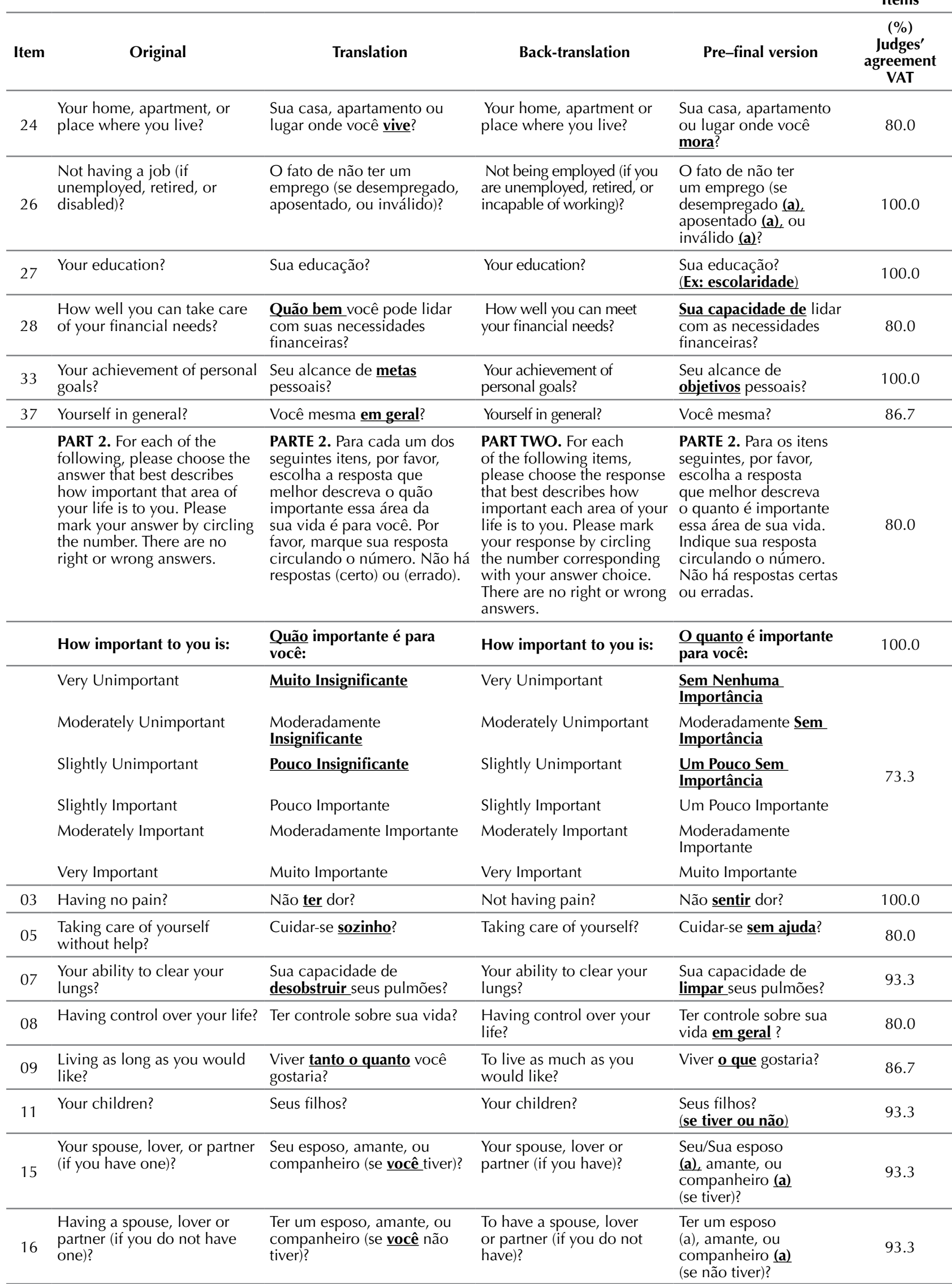




\begin{tabular}{|c|c|c|c|c|c|}
\hline Item & Original & Translation & Back-translation & Pre-final version & $\begin{array}{c}(\%) \\
\text { Judges' } \\
\text { agreement } \\
\text { VAT }\end{array}$ \\
\hline & Please Go To Next Page & $\begin{array}{l}\text { Por favor vá para a próxima } \\
\text { página }\end{array}$ & Please go to the next page & $\begin{array}{l}\text { Por favor passe para a } \\
\text { próxima página }\end{array}$ & 100.0 \\
\hline 18 & $\begin{array}{l}\text { The emotional support you } \\
\text { get from your family? }\end{array}$ & $\begin{array}{l}\text { O apoio emocional que você } \\
\text { tem de sua família? }\end{array}$ & $\begin{array}{l}\text { The emotional support you } \\
\text { get from your family? }\end{array}$ & $\begin{array}{l}\text { O apoio emocional que } \\
\text { recebe de sua família? }\end{array}$ & 93.3 \\
\hline 19 & $\begin{array}{l}\text { The emotional support you } \\
\text { get from people other than } \\
\text { your family? }\end{array}$ & $\begin{array}{l}\text { O apoio emocional que você } \\
\text { tem de pessoas que não são } \\
\text { de sua família? }\end{array}$ & $\begin{array}{l}\text { The emotional support you } \\
\text { get from people outside of } \\
\text { your family? }\end{array}$ & $\begin{array}{l}\text { O apoio emocional que } \\
\text { recebe de pessoas além } \\
\text { de sua família? }\end{array}$ & 100.0 \\
\hline 24 & $\begin{array}{l}\text { Your home, apartment, or } \\
\text { place where you live? }\end{array}$ & $\begin{array}{l}\text { Sua casa, apartamento, ou } \\
\text { lugar onde você vive? }\end{array}$ & $\begin{array}{l}\text { Your home, apartment, or } \\
\text { place where you live? }\end{array}$ & $\begin{array}{l}\text { Sua casa, apartamento, } \\
\text { ou lugar onde você } \\
\text { mora? }\end{array}$ & 73.3 \\
\hline 26 & $\begin{array}{l}\text { Having a job (if unemployed, } \\
\text { retired, or disabled)? }\end{array}$ & $\begin{array}{l}\text { Ter um emprego (se } \\
\text { desempregado, aposentado } \\
\text { ou inválido)? }\end{array}$ & $\begin{array}{l}\text { Having a job (if unemployed, } \\
\text { retired, or unable to work)? }\end{array}$ & $\begin{array}{l}\text { Ter um emprego (se } \\
\text { desempregado }(\mathbf{a})_{1} \\
\text { aposentado }(\mathbf{a}) \text { ou } \\
\text { inválido }(\mathbf{a}) \text { ? }\end{array}$ & 100.0 \\
\hline 27 & Your education? & Sua educação? & Your education? & $\begin{array}{l}\text { Sua educação? (ex: } \\
\text { escolaridade) }\end{array}$ & 100.0 \\
\hline 29 & Doing things for fun? & Fazer coisas por diversão? & Doing things for fun? & $\begin{array}{l}\text { Fazer coisas para se } \\
\text { divertir? }\end{array}$ & 40.0 \\
\hline 31 & Peace of mind? & Paz de espírito? & Peace of mind? & Sua paz de espírito? & 100.0 \\
\hline 33 & $\begin{array}{l}\text { Achieving your personal } \\
\text { goals? }\end{array}$ & Alcance de metas pessoais? & Reaching personal goals? & $\begin{array}{l}\text { A realização de } \\
\text { objetivos pessoais? }\end{array}$ & 53.3 \\
\hline 37 & Are you to yourself? & $\begin{array}{l}\text { O que você é para você } \\
\text { própria? }\end{array}$ & What you mean to yourself? & Ser você mesma? & 73.3 \\
\hline
\end{tabular}

Chart 1 - Modifications of index items made by the patients during the pretest parts 1 and 2 - Fortaleza, CE, Brazil, 2014.

\begin{tabular}{|c|c|c|}
\hline Item nr & According to judges & According to patients \\
\hline $\mathbf{6}$ & Your ability to go places outside your home? & $\begin{array}{c}\text { Your ability to go places outside your home? (Church, } \\
\text { supermarket, visiting relatives...) }\end{array}$ \\
\hline $\mathbf{7}$ & Your ability to clean your lungs? & Your ability to eliminate secretions from the lungs? \\
\hline $\mathbf{8}$ & Control you have over your life? & The control you have over your life in general? \\
\hline $\mathbf{9}$ & Your chance to live as long as you would like? & $\begin{array}{c}\text { Your chance to live what you would like? } \\
\mathbf{1 5}\end{array}$ \\
\hline $\mathbf{1 6}$ & Your spouse, lover or partner (if you have one)? & $\begin{array}{c}\text { Your spouse, partner or person you have a sexual } \\
\text { relationship with (if you have one)? }\end{array}$ \\
\hline
\end{tabular}

Source: Developed by the authors.

\section{DISCUSSION}

Regarding socio-economic variables, the present study findings are supported by national and international literature when pointing out that most people with SCI are young or young adults and male $e^{(11-14)}$.

Given the severity and irreversibility of spinal cord injuries, a long rehabilitation program is required for improving the QOL of individuals. In most cases the program does not cure, but helps in adapting to a new life ${ }^{(12)}$. However, as noted, large numbers of people did not undergo rehabilitation (63.3\%) after SCI. Such fact is related to clinical complications resulting from spinal cord injury, among which the pressure ulcers stand out.
A study on the profile of patients with traumatic SCI points to the occurrence of pressure ulcers in $42.5 \%$ of the subjects. This delays or hinders the rehabilitation process, since rehabilitation centers only receive patients with intact skin. In addition, other factors such as income and education interfere in the rehabilitation process ${ }^{(15)}$.

Regarding the causes of SCI in Brazil, a study ${ }^{(16)}$ identified similar data, showing that SCI was due to assaults with FAP (63.3\%) and car accident traumas (20\%), highlighting the violence context in Brazilian cities, and 20\% resulted from high falls.

In order to obtain a specific index for people with SCI in the Brazilian population, was conducted a cross-cultural adaptation of the Quality of Life Index Spinal Cord Injury - 
Version III. Thus, some changes were made when drafting the instructions of the items and in the designation of answers in part two, which had a very cultured vocabulary. Other changes were adding expressions or words of explanation at the end of the question, substitution of words and terms and addition of articles or pronouns for gender agreement.

The cross-cultural adaptation process of instruments elaborated in another culture and/or language should comprise a combination between a literal translation of words and phrases from one language to another, and a meticulous adjustment process that addresses the cultural context and lifestyle of the target population of the version ${ }^{(17)}$.

Another study ${ }^{(18)}$ carried out the cross-cultural adaptation using the generic version of the index. In item 29 (Doing things for fun?), the same cross-cultural adaptation was found. However, the item is discussed in relation to the financial limitations that compromised the participation of these people in leisure activities.

This aspect differed from the findings of the present study because for many patients, the financial conditions did not affect the performance of these activities. A group of patients participating in a basketball selection for disabled stood out. Regarding the other items, there was no discussion contrary to what was already confirmed by the results.

The kappa coefficient was calculated as a statistical measure that demonstrates the stability of the instrument items. In this calculation were compared the responses of judges with regard to the semantic, spelling, vocabulary and grammar equivalences. However, there are no references from other studies that have employed this index on the kappa values in order to discuss about them.

After exhaustive search for articles using this index an only study was found, in which publications about the versions of the overall index were surveyed, but there was no access to the work in full for more depth and discussion. No studies inherent to the specific index for people with SCI were identified ${ }^{(19)}$.

\section{CONCLUSION}

The judges' cultural adaptation of the Portuguese version of the Quality of Life Index Spinal Cord Injury - Version III showed that the instrument is suitable from the semantic, idiomatic, experimental and conceptual points of view, of easy application to evaluate the QOL of people with SCI, encompassing the domains of family, health and functioning, as well as economic, social, psychological and spiritual issues.

The index can be used by professionals in the evaluation of QOL of people with SCI, and assist with expanding the scientific community knowledge. Therefore, the instrument is a self-applied technology that measures subjective relationships and enables interventions, the planning and evaluation of care focused on the peculiar needs of individuals with spine cord injury.

\section{RESUMO}

Objetivo: Traduzir e adaptar culturalmente para a língua portuguesa o Ferrans and Powers Quality of Life Index Spinal Cord Injury - Version III e caracterizar amostra quanto aos aspectos sociodemográficos e clínicos. Método: Estudo metodológico com vistas à adaptação transcultural, seguindo as etapas própias deste método: tradução inicial, síntese da tradução, tradução de volta à língua original (back-translation), revisão por um comitê de juízes e pré-teste da versão final. Realizou-se pré-teste com 30 pacientes com lesão medular. Resultados: Obteve-se índice com 74 itens, divididos em duas partes (satisfação/importância). Os critérios de equivalência semântica foram avaliados como tradução muito adequada, superior a $87 \%$, vocabulário e gramática superior a $86 \%$. Idiomática superior a 74\%, experimental superior a 78\% e conceitual superior a 70\%. Conclusão: Após adaptado transculturalmente o instrumento mostrouse adequado semântica, idiomática, experimental e conceitualmente, além de facilitar a avaliação da qualidade de vida de pessoas com lesão medular.

\section{DESCRITORES}

Traumatismos da Medula Espinhal; Qualidade de Vida; Comparação Transcultural; Estudos de Validação; Enfermagem em Reabilitação.

\section{RESUMEN}

Objetivo: Traducir y adaptar culturalmente a la lengua portuguesa el Ferrans and Powers Quality of Life Index Spinal Cord Injury Version III y caracterizar la muestra en cuanto a los aspectos sociodemográficos y clínicos. Método: Estudio metodológico con vistas a la adaptación transcultural, siguiendo las etapas propias de ese método: traducción inicial, síntesis de la traducción, traducción de vuelta a la lengua original (back-translation), revisión por un comité de jueces y pre prueba de la versión final. Se llevó a cabo una pre prueba con 30 pacientes con lesión medular. Resultados: Se logró índice con 74 puntos, divididos en dos partes (satisfacción/importancia). Los criterios de equivalencia semántica fueron evaluados como traducción muy adecuada, superior al $87 \%$, vocabulario y gramática superior al $86 \%$, idiomática superior al 74\%, experimental superior al 78\% y conceptual superior al 70\%. Conclusión: Después de adaptado transculturalmente, el instrumento se mostró adecuado semántica, idiomática, experimental y conceptualmente, además de facilitar la evaluación de la calidad de vida de personas con lesión medular.

\section{DESCRIPTORES}

Traumatismos de la Médula Espinal; Calidad de Vida; Comparación Transcultural; Estudios de Validación; Enfermería en Rehabilitación.

\section{REFERENCES}

1. Carvalho ZMF, Mulet FVF, Nuñez AJH, Brito AMC, Gularte TM, Mulet CS. El cuidado de enfermería en la percepción de los familiares personas ingresadas con lesión medular. Enferm Integral. 2009;85(1):30-5. 
2. Carvalho ZMF, Darder JJT, Reis PAM, Magalhães SR, Maniva SJCF. Experiencing a traumatic spinal cord injury: analysis on the view of the theory of Watson's transpersonal caring. J Biom Sci Eng. 2013;6(1):14-20.

3. Instituto Brasileiro de Geografia e Estatística (IBGE). Censo Demográfico 2010: resultados gerais da amostra [Internet]. Rio de Janeiro; 2013 [citado 2013 ago. 17]. Disponível em: http://www.ibge.gov.br

4. Fleck MPA, Leal OF, Louzada S, Xavier M, Chachamovich E, Vieira G, et al. Development of the Portuguese version of the instrument for assessing quality of life in WHO (WHOQOL-100). Rev Bras Psiquiatr. 1999;21(1):19-28.

5. Ferrans C, Powers M. Psychometric assessment of the Quality of Life Index. Res Nurs Health. 1992;15(1):29-38.

6. Beaton DE, Bombadier C, Guillemin F, Ferraz MB. Recommedations for the cross-cultural adaptation of health status measures. New York: American Academy of Orthopedic Surgeon, Institute for Work \& Health; 2002.

7. Beaton DE, Bombadier C, Guillemin F, Ferraz MB. Guidelines for process of cross-cultural adaptation of self-report measures. Spine. 2000;25(24):3186-91

8. Joventino ES, Oriá MOB, Sawada NO, Ximenes LB. Apparent and content validation of maternal self-efficiency scale for prevention of childhood diarrhea. Rev Latino Am Enfermagem [Internet]. 2013 [cited 2013 Aug 18];21(1):371-9. Available from: http://www.scielo.br/ $\mathrm{pdf} / \mathrm{rlae} / \mathrm{v} 21 \mathrm{n} 1 / \mathrm{v} 21 \mathrm{n} 1 \mathrm{a} 12 . \mathrm{pdf}$

9. Ferrans CE, Powers M. Ferrans and Powers Quality of Life Index [Internet]. [cited 2013 Aug 18]. Available from: http://www.uic.edu/orgs/qli/

10. Brasil. Ministério da Saúde; Conselho Nacional de Saúde. Resolução n. 466, de 12 de dezembro de 2012. Dispõe sobre diretrizes e normas regulamentadoras de pesquisas envolvendo seres humanos [Internet]. Brasília; 2012 [citado 2013 jun. 15]. Disponível em: http://conselho. saude.gov.br/resolucoes/2012/Reso466.pdf

11. Coura AS, Enders BC, França ISX, Vieira CENK, Dantas DNA, Menezes DJC. Ability to self-care and its association with sociodemographic factors in persons with spinal cord injury. Rev Esc Enferm USP [Internet]. 2013 [cited 2013 Aug 17];47(5):1154-62. Available from: http:// www.scielo.br/pdf/reeusp/v47n5/0080-6234-reeusp-47-05-1150.pdf

12. Bampi LNS, Guilhem D, Lima DD. Qualidade de vida em pessoas com lesão medular traumática: um estudo com o WHOQOL-bref. Rev Bras Epidemiol. 2008;11(1):67-77.

13. Schoeller SD, Borges AMF, Brignol P, Kuhnen AE. Conhecer para cuidar características de pessoas com lesão medular atendidas em um centro de reabilitação. Rev Pesq Cuid Fundam. 2012;4(3):2598-604.

14. Cripps RA, Lee BB, Wing P, Weerts E, Mackay J, Brown D. A global map for traumatic spinal cord injury epidemiology: towards a living data repository for injury prevention. Spinal Cord. 2011;49(4):493-501.

15. Brunozi, AE, Silva, AC, Gonçalves, LF, Veronezi, RJB. Qualidade de vida na lesão medular traumática. Rev Neurocienc. 2011;19(1):139-44.

16. Blanes L, Lourenço L, Camagnani MIS, Ferreira LM. Clinical and socio-demographic characteristics of persons with traumatic paraplegia in São Paulo, Brazil. Arq Neuro-Psiquiatr. 2009;67(2):388-90.

17. Reichenheim ME, Moraes CL. Operacionalização de adaptação transcultural de instrumentos de aferição usados em epidemiologia. Rev Saúde Pública. 2007;41(4): 665-73.

18. May LA, Warren S. Measuring quality of life of persons with spinal cord injury: Substantive and structural validation. Qual Life Res. 2001;10(6):503-15.

19. Oliveira AS, Santos VLCG. Responsiveness of instruments to assess quality of life Ferrans and Powers: a literature review. Acta Paul Enferm. 2011;24(6):839-44. 